The Social Sciences 7 (4): 510-516, 2012

ISSN: $1818-5800$

(C) Medwell Journals, 2012

\title{
The Impact of Asian Financial Crisis to Earnings Management and Operating Performance in Malaysia
}

\author{
${ }^{1}$ Rosnia Masruki and ${ }^{2}$ Noor Azlinna Azizan \\ ${ }^{1}$ Islamic Science University of Malaysia, Malaysia \\ ${ }^{2}$ Universiti Malaysia Pahang, Malaysia
}

\begin{abstract}
This study is motivated by the emergence of different trend between Cash from Operations (CFO) and net income reported by companies. The objective of this study is to investigate the relationship between the operating performances of top 100 market firms listed on the Main Board of the Bursa Malaysia and the behaviour of net income after Asian financial crisis. Initially the sample firms are divided into 10 portfolios based on relative Cash from Operations ( $\mathrm{CFO}$ ) rankings to test if there are systematic differences in $\mathrm{CFO}$ across portfolios. A correlation test and a sign-change ratio test are used to study if operating performances and net income are interrelated. The empirical evidence supports the predictions. It suggests that firms from various industries manage earnings when operating performance is poor. The firms tend to choose income-increasing strategies, specifically when the operating performance is extremely poor. In fact, some firms tend to take a big bath whereas some of the exceptionally well performing firms tend to select income-decreasing strategies.
\end{abstract}

Key words: Earnings management, Cash from Operations $(\mathrm{CFO})$, Net Income (NI), market firms, industries, Malaysia

\section{INTRODUCTION}

Financial measures are the starting point for most company performance measurement systems. For corporations, these financial measures come directly from (or are calculated using) accounting information from the regulatory financial statements. Although, the rules of accounting attempt to be specific, at times their interpretation misses the mark. Levitt (1998) US Securities and Exchange Commission (SEC) Chairman decried what he termed as accounting hocus-pocus and called for coordinated efforts to uncover it (Levitt, 1998). He targeted the practice by some companies of improper boosting reported earnings by manipulating the recognition of revenue. Chung et al. (2004) investigated the relationship between free cash flow and discretionary accruals and found that there is a positive relationship between free cash flow and discretionary accruals. Companies with high free cash flows use incomeincreasing discretionary accruals to camouflage the earnings impact of non-value maximizing investment and other expenses. Several related studies also suggest that managers manipulate reported profits (earnings management) to fit their intention by selecting certain accounting policies, changing accounting estimates and managing accruals. They engage in earnings management for various reasons. They may have incentives to manage earnings to smooth reported earnings to boost stock price, to decrease income tax expense to make firms look better, to maximize managers compensation or to decrease political visibility. In fact, growing bodies of research and several independent researchers have examined the issues on earnings management. The relevance of earnings figures has been a topic of an on-going debate. Instead of using accounting numbers of earnings, cash from operations is expected to be a more reliable indicator of the performance of the company than reported earnings (Healy and Healy, 1985). In addition, cash also is more direct liquidity measure than earnings. Thus, the present study extends this line of research by investigating the relationship Between Cash from Operations (CFO) and net income after Asian financial crisis. Companies are expected to have more cash if they earned higher profit. Nevertheless, this scenario is not exactly happen in most of the companies. In particular, the present study attempts to discover the association between cash from operations and earnings management after Asian economic crisis. The main objective of this study is to analyse whether among top 100 market firms of the Bursa Malaysia have incentives to manage earnings depending upon their operating performances after Asian economic crisis. Since, the cash flow is expected to be a more reliable indicator of the company's performance (Healy and Healy, 1985) this study employs the measurement of Cash from

Corresponding Author: Rosnia Masruki, Islamic Science University of Malaysia, Malaysia 
Operations (CFO), it's level and changes instead of Net Income $(\mathrm{NI})$. The specific objectives of investigating the earnings management are to examine:

- Correlation between $\mathrm{CFO}$ and NI

- The proportion of sign changes of $\mathrm{CFO}$ and net income across firms portfolios

Literature review: A number of previous studies were reviewed to provide better insight into various aspects concerning earnings management issues. The areas covered can be decomposed into several hypotheses related to income smoothing, management compensation, ownership control or management buyout and political costs.

Income smoothing: The conception that firms use accounting techniques to smooth or normalize earnings have been long discussed in the accounting literatures. Several reasons may contribute to the managers incentives to report higher earnings with respect to customers, suppliers, lenders and employees particularly, for the following reasons:

- Customers are willing to pay a higher price for goods because the firm is assumed more likely to recognize implicit warranty and service commitments

- Suppliers offer better terms because the firm is more likely to make payments due for current purchases and because the firm is more likely to make larger future purchases

- Lenders offer better terms because the firm is less likely to either default or delay loan payments

- Valuable employees are less likely to leave when company is stable and future looks good

However, there may also other factors that discourage managers to report higher earnings probably in lieu of wage negotiations with unions (Liberty and Zimmerman, 1986) and tax charges. Jones (1991) tested and found support that managers make income decreasing accruals during import relief investigations. Moses (1987) used accounting changes as a measure of discretionary accruals and found that smoothing is associated with firm size, the existence of bonus plans and the divergence of actual earnings from expectations. The smoothing is employed by changing accounting that associated with the impact of the accounting change on the level of earnings. Unfortunately, this study only test for the existence of smoothing but does not explain managerial motivation for engaging in smoothing. The standard smoothes income by reducing the variability of reported earnings through excluding transactions gains and losses from annual income. The significant insider trading volumes around the announcement date of the second exposure draft provides effect of some income smoothing activity. Since, the decision to adopt the standard early was a discretionary action to the managements, this is one possible reason that they can engage in income smoothing activity. Chaney and Lewis (1998) mentioned that there is a positive association between a proxy for income smoothing and firm performance. Meaning that, firms that perform well tend to report earnings with less variability relative to cash from operations compared to other firms. They extend the analysis with Initial Public Offering (IPO) and showed that IPO firms tend to use discretionary accruals to smooth income relative to the prior year's earnings.

Management compensation: Managers act to maximize their own wealth and their wealth is affected by a firm's stock price and the manager's compensation package includes bonus incentive. Several previous studies have indicated that bonus plans provide incentives to adjust the level of earnings. In fact, Moses (1987) proved that bonus plans also provide incentives to avoid fluctuations in earnings. Specifically, bonus schemes create incentives for managers to select accounting procedures and accruals to maximize the value of their bonus awards. There is a strong relationship between accrual policies and managers income-reporting incentives under their bonus contracts (Healy and Healy, 1985). Reitenga et al. (2002) extended Healy and Healy (1985) found evidence that executives in firms that qualify their compensation plans receive relatively low pay when their firm's financial performance is extreme. This result is consistent with prior research (Healy and Healy, 1985) specifically bonus compensation is driven by some form of accounting earnings. Thus, have incentives to smooth reported earnings over time in order to maximize long-term compensation. The relatively smooth earnings pattern in this study is related to the use of discretionary accruals. It is thought that discretionary accruals can be successfully managed for the purpose of executive compensation because compensation committees have little direct incentive to uncover and adjust such earnings management (DeAngelo, 1988).

Ownership control or management Buyout: Agency theory indicates that accounting numbers play a vital role to mitigate conflicts of interest between insider-managers and outside stockholders of public corporations. These conflicts are particularly in a management buyout or going private transactions through which managers of a public corporation purchase all common stock held by outsiders. DeAngelo (1986) studied the accounting decisions made 
by managers of 64 New York and American Stock Exchange firms who proposed to purchase all publicly held common stock and go private during 1973-1982. She failed to find support that managers have incentives to understate reported income in attempts to reduce the buyout compensation. Perry and Williams (1994) expanded the sample to 175 management buyouts during 1981-1988 and in contrast, provides evidence of manipulation of discretionary accruals in the predicted direction in the year preceding the public announcement of management's intention to bid for control of the company. DeAngelo (1988) inferred that managers of firms in proxy contests exercise their accounting discretion at paint a more favourable picture of their own performance to voting stockholders. Then if elected, dissident tend to take an immediate earnings bath. The managers typically blame prior management for the previous poor operating performance. In general, the owner manager is less concerned about the labour market effects than the professional manager, it can be expected that the new accounting rule to have a greater wealth effect for managers of manager-controlled firms than for managers of owner-controlled firms. Vafeas et al. (2003) examined the important area of earnings management preceding self-tender offers for a sample of US firms. They reported weak evidence of biased accruals reporting by managers around self-tender offers. In this case, repurchases may not provide strong incentives and opportunities for earnings management. Bauwhede et al. (2003) found that Belgian companies both private and public engage in income smoothing and manage earnings opportunistically to meet benchmark target of prior year earnings. But when companies have earnings above target then have incentives to smooth earnings downwards.

Political costs: Prior research has examined the effect of costs due to political activity (political costs) resulting from import restriction hearings (Jones, 1991) and antitrust investigations (Cahan, 1992) but the effect of political costs arising from rapid consumer product price increases was yet to be tested by Han and Wang (1998). Specifically, they study on the sudden increase in gasoline prices in the wake of 1990 Gulf crisis made oil firms vulnerable to political actions. Indeed, result of this study proposed that consumer product firms encountering unusual increases of product prices have incentives to decrease reported earnings to minimize political sensitivity and related costs. Kanagaretnam et al. (2003) discovered that the propensity to signal is not cross-sectionally constant; it varies negatively with bank size and positively with earnings variability, future investment opportunities and degree of income smoothing. In summary as demonstrated by the literatures presented in this study, there are several hypotheses of earnings management and mixed results on the association between the operating performances and the behaviour of accruals. Specifically, different firms have different degree of incentives to manage earnings depending upon their operating performances. But, this study will analyse the relationship between operating performances, i.e., cash from operations and reported net income, focusing on firms listed on the Main Board of the Bursa Malaysia after Asian financial crisis for the financial year ended of 1999 through 2002. The findings of the present study will add to the expanding literature that addresses the incentives of earnings management depend upon firm operating performances particularly, to look at the immediate effect from Asian economic crisis in 1997 and 1998 in the context of Malaysian financial reporting.

\section{MATERIALS AND METHODS}

Sampling design: The sample includes firms listed on the Main Board of the Bursa Malaysia for the financial year ended 1999 through 2002. This period chosen is to reflect the immediate effect of Asian financial crisis. The 4 years period is adequate to reduce classification error (Copeland, 1968). A sample selection in this study was randomly selected from the list of firms on the Main Board of the Bursa Malaysia. Consistent with the sampling method used by Awang et al. (2004), the simple random sampling was used to arrive at a sample of 30 companies for each sector of trading/services, consumer, industrial, construction, properties and plantation. The firms listed under the mining sector were combined into the plantation sector whereas the hotel companies were combined into the properties sector. This was done as the number of firms listed under these sectors was too small and the combination was based on close similar industry. Excluded were all companies classified under the finance sector (58 companies) which is considered to have a very different financial structure and nature of business. Apart from this, companies that had been de-listed (62 companies) during the studied period were also excluded. This was to ensure that the sample selected from the population comprised listed companies that existed throughout the period under study. About 14 companies with missing data also did not include in this study. As at 31 December 1999, there were 474 companies listed on the Main Board only, excluded listed companies on the Second Board. They are chosen in order to minimize potential econometric problems, i.e., scale bias and heteroscedastic (Heteroscedasticity disturbances arise from the fact that large or small companies tend to produce large or small disturbances) disturbances. Therefore, from the population of 474 firms only 271 firms remained as the total number of population for the study after considering the criteria discussed before. From the 
six selected sectors, a sample of 180 firms divided equally for each sector based on annual reports for the financial year ending on December, 1999 was selected. The sample size represented $66.42 \%$ of the total population.

Data collection: The accounting data used in this study consists of raw data for the financial year ended 1998 through 2002 obtained from both the Annual Corporate Handbook (Malaysia) and the Bursa Malaysia websites were used to identify firms listed on the Main Board of the Bursa Malaysia. A summary of the variables of interest is shown in Table 1. In this study, the data had been analysed using the software of SPSS 11.0 and Microfit 4.0 to examine any systematic differences in firms operating performances. Prior to the test, expectation was being made that operating performances measured in terms of Cash from Operations (CFO) and net income have positive relationship. To begin the analysis, 10 Cash from Operations ( $\mathrm{CFO}$ ) portfolios were constructed to detect any systematic differences in $\mathrm{CFO}$ growth across portfolios (McNichols and Wilson (1988) divided the sample firms into 10 portfolios based on relative $\mathrm{CFO}$ rankings). The current study is attempt to investigate whether top 100 market firms listed on the Main Board of the Bursa Malaysia have different trend on operating performances measured in terms of $\mathrm{CFO}$ and net income after Asian financial crisis. Therefore, it is practical to divide the sample into two groups of positive and negative-growth of $\mathrm{CFO}$ portfolios to proceed with more conclusive and clearer analysis. Correlation test similar to t-test was used to analyze the correlation between $\mathrm{CFO}$ and $\mathrm{NI}$ for each portfolio, particularly the mean differences in accruals between negative $\mathrm{CFO}$ firms and positive $\mathrm{CFO}$ firms. Finally, sign-change test between net income and $\mathrm{CFO}$ which is a nonparametric test is employed to examine the proportions of sign change across the portfolios of negative and positive $\mathrm{CFO}$ growth firms.

Research hypothesis: In order to ensure that the research objectives are achieved, hypotheses testing were developed. It is used to make inference about a population and to ensure that enough statistical evidence

Table 1: Variables required for regression

\begin{tabular}{|c|c|c|}
\hline Variables & Measure of variables & Symbols \\
\hline Net income & $\begin{array}{l}\text { Profit/Loss after tax and minorities but } \\
\text { before extraordinary items }\end{array}$ & NI \\
\hline Cash from operation & $\begin{array}{l}\text { Funds generated from operations extracted } \\
\text { from cash flow statements }\end{array}$ & CFO \\
\hline Operating profit & $\begin{array}{l}\text { Operating profit extracted from financial } \\
\text { statement }\end{array}$ & OPR \\
\hline Change in cash & $\begin{array}{l}\text { Current y ear cash balance minus prior } \\
\text { year cash balance }\end{array}$ & $\triangle \mathrm{CASH}$ \\
\hline
\end{tabular}

exists to conclude that a belief on hypothesis about a parameter is reasonable. The hypotheses tested were listed as:

$\mathrm{H}_{1}$ : There is a positive correlation between $\mathrm{CFO}$ and $\mathrm{NI}$ since both variables represent operating performance indicators

In contrast with the presence of earnings management a negative correlation might be found, particularly in some extreme cases. Therefore, when firms manage earnings it is not necessarily to find strong positive correlation between $\mathrm{CFO}$ and $\mathrm{NI}$ for each portfolio.

$\mathrm{H}_{2}$ : There is a negative relationship between $\mathrm{CFO}$ and NI. Specifically, negative $\mathrm{CFO}$ firms may have incentives to report positive NI figures

If the magnitudes of negative firms are not too great, they can manipulate some accounting accruals easily to have positive earnings in the financial statement. Thus, there is a higher sign-change ratio. However, significant negative firms are difficult in finding large enough accounting accruals to report positive earnings. Relating to the constructed portfolios, it is expected that lower proportion of sign change in the positive $\mathrm{CFO}$ portfolios and conversely, negative $\mathrm{CFO}$ firms have higher proportion of sign change between $\mathrm{CFO}$ and $\mathrm{NI}$.

\section{RESULTS AND DISCUSSION}

Statistical analysis: In order to test the hypotheses, all variables of interest were ascertained to be available in the chosen sample of 720 firms listed on the main board in various industries. However, before pooling the data across firms and years $10 \mathrm{CFO}$ portfolios were constructed as established by McNichols and Wilson (1988) to investigate whether there is any systematic difference in Cash from Operations ( $\mathrm{CFO}$ ). Table 2 shows the descriptive statistics for the relevant variables on the sample of 720 firms listed on the Main Board of the KLSE. The higher the mean and standard deviation, the noisier measure of earnings management is. The current sample studied shows that the mean and standard deviation of the cash flow level are at its highest signifying that the

Table 2: Descriptive statistics for pooled sample of top 100 firms

\begin{tabular}{lccccc}
\hline Parameters & $\mathrm{N}$ & Minimum & Maximum & Mean & SD \\
\hline NI & 720 & $-3.1 \mathrm{E}+9$ & $2.1 \mathrm{E}+9$ & $9.4 \mathrm{E}+7$ & 361537872 \\
CFO & 720 & 261238 & $1.1 \mathrm{E}+10$ & $5.4 \mathrm{E}+8$ & 1197455816 \\
$\Delta \mathrm{CFO}$ & 720 & $-8.4 \mathrm{E}+9$ & $7.3 \mathrm{E}+9$ & $-2.3 \mathrm{E}+7$ & 1013285680 \\
\multicolumn{2}{l}{ NI: Net Income; CFO: Cash from Operations; OPR: Operating Profit }
\end{tabular}


The Soc. Sci., 7 (4): 510-516, 2012

Table 3: Correlation test between NI and CFO

\begin{tabular}{|c|c|c|c|c|}
\hline \multirow[b]{2}{*}{ CFO level } & \multirow[b]{2}{*}{ Portfolio } & \multirow[b]{2}{*}{ Sub-samples } & \multicolumn{2}{|c|}{ Pearson correlation } \\
\hline & & & Coefficient & t-ratio \\
\hline \multirow[t]{5}{*}{ Negative } & 1 & 31 & 0.551 & $8.53^{\text {*** }}$ \\
\hline & 2 & 32 & 0.095 & 1.45 \\
\hline & 3 & 32 & 0.084 & 0.17 \\
\hline & 4 & 32 & 0.064 & 0.04 \\
\hline & 5 & 32 & -0.056 & -0.01 \\
\hline \multirow[t]{8}{*}{ Positive } & 6 & 33 & 0.464 & 0.33 \\
\hline & 7 & 33 & 0.206 & 0.26 \\
\hline & 8 & 33 & 0.051 & 0.08 \\
\hline & 9 & 33 & -0.258 & -0.01 \\
\hline & 10 & 33 & 0.383 & 0.33 \\
\hline & Negative & 159 & 0.470 & 15.18 \\
\hline & Positive & 165 & 0.220 & 10.05 \\
\hline & Total & 324 & 0.471 & 25.01 \\
\hline
\end{tabular}

****Significant at the 0.01 level

level of cash from operations will greatly influence management to manage income. This result is similar to majority of the researches such as Holland and Ramsay (2003), Burgstahler and Dichev (1997) and Chaney and Lewis (1998).

Correlation tests between cash from Operations (CFO) and Net Income (NI): The correlation coefficient used in this study is to measure the closeness of a relationship between NI and CFO. Pearson correlation coefficient was used to establish the strength of relationship between NI and $\mathrm{CFO}$ as well as the direction of the association between two variables. As a basic concept, if correlation coefficient is positive or negative 1.00 , it signifies a strong relationship whereas the sign positive or negative is the matter of positive and inverse relationship, respectively. Prior expectation is that there is a positive relationship between NI and CFO without earnings management because both variables represent operating performance (McNichols and Wilson, 1988) reported a positive correlation of 0.54 between $\mathrm{CFO}$ and NI. However when firms manage earnings, it is not necessarily find this strong positive correlation in some extreme cases). A low correlation between the two indicators will therefore, imply the evidence of earnings management practice. In this study, correlation matrix of NI and CFO for pooled sample of 720 firms for the period 1999-2002 is 0.471. This reveals that there is a positive relationship between NI and $\mathrm{CFO}$ but the strength of the association is weak. Therefore to get clearer picture, Table 3 provides the results of correlation between NI and $\mathrm{CFO}$ for each portfolio. The results of the correlation coefficient tests between $\mathrm{NI}$ and $\mathrm{CFO}$ are quite low ranging from -0.0560.551 in the case of Pearson correlation and even negative for some portfolios (portfolios 5 and 9). The correlation analysis indicates that the extremely poor performers are quite different from the other portfolios. Interestingly, portfolio 1 firms actually take big bath strategies. The

\begin{tabular}{lcccc}
\multicolumn{2}{l}{ Table 4: Sign-change ratio test } \\
& & \multicolumn{3}{c}{ Sign-change } \\
CFO growth & Portfolio & Sub-samples & Observations & ratio (\%) \\
\hline Negative & 1 & 69 & 44 & 63.8 \\
& 2 & 69 & 58 & 84.1 \\
& 3 & 69 & 58 & 84.1 \\
& 4 & 69 & 65 & 94.2 \\
Positive & 5 & 69 & 67 & 97.1 \\
& 6 & 75 & 5 & 06.7 \\
& 7 & 75 & 7 & 09.3 \\
& 8 & 75 & 18 & 24.0 \\
& 9 & 75 & 1 & 03.0 \\
& 10 & 75 & 11 & 14.7 \\
& Negative & 345 & 292 & 84.6 \\
& Positive & 375 & 42 & 11.2 \\
& Total & 720 & 334 & 46.4 \\
\hline
\end{tabular}

Pearson correlation coefficients between the two performance indicators are positive and highly significant ( 0.551 with a t-ratio of 8.53 ). Overall, the correlation analysis is consistent in showing that firms with negative $\mathrm{CFO}$ manage earnings more heavily than the positive $\mathrm{CFO}$ firms.

Sign-change ratio tests: The two parametric tests (the correlation test and the regression analysis) may be plagued by outliers that may have a significant misleading effect on the results. Therefore, the final test, i.e., signchange test is a nonparametric test in the sense that outliers should not affect the results. This test implies that negative $\mathrm{CFO}$ firm reports positive earnings figure (income-increasing strategies) or positive $\mathrm{CFO}$ firm reports negative earnings figure (income-decreasing strategies). Table 4 shows the result of the sign-change ratio test. The results clearly and consistently reveal that a majority of $84.6 \%$ of negative firms manages earnings too extensively to report positive earnings. However, portfolio 1 firms (36.2\%) may not be able to report positive earnings without massive earnings management since, these firms are experiencing severe negative cash from operations.

In this case, it is believed that these types of firms may employ various vehicles to manage earnings. In contrast, the rest of negative $\mathrm{CFO}$ portfolios may be in better position comparatively to employ income increasing strategies available. To conclude the analysis in sign-change tests for negative $\mathrm{CFO}$ firms, a gradual increase in sign changes as $\mathrm{CFO}$ increase is in line with prior expectation. However, in general the positive $\mathrm{CFO}$ firms do not report negative earnings (except portfolio 8 and 10). Although, portfolio 8 and 10 firms reported high sign-change ratios within the group of positive $\mathrm{CFO}$, the ratios are much lower than negative CFO. As expected, the low sign-change ratios for positive $\mathrm{CFO}$ because they have no reason to report negative earnings. 
The correlation between $\mathbf{C F O}$ and $\mathbf{N I}\left(\mathbf{H}_{1}\right)$ : Although, the estimated correlation matrix of NI and $\mathrm{CFO}$ for pooledsample of 720 firms for the period 1999-2002 is rather weak but more clearer understanding when correlate the CFO and NI by portfolios. Hypothesis 2 is supported whereby there is a positive relationship between $\mathrm{CFO}$ and NI. This is supported by McNichols and Wilson (1988) where they found a positive correlation of 0.54 between CFO and NI as both indicators measure firms performance. However, there is some exception to the extreme poor performers and bad performers. The correlation analysis states that they are quite different from the other portfolios. From the result, portfolio 5 and 9 have negative relationship between $\mathrm{CFO}$ and NI. The exceptional finding is consistent with Yoon and Miller (2002).

The relevant of CFO with $\mathbf{N I}\left(\mathbf{H}_{2}\right)$ : With reference to the sign-change ratio test, there is a conclusive result pertaining to the CFO with NI. Table 4 shows the result which implies that negative $\mathrm{CFO}$ firms report positive earnings $(84.6 \%)$. On the other hands only $11.2 \%$ of positive $\mathrm{CFO}$ firms have incentive to report negative earnings, most probably to reduce tax charges (Jones, 1991). Although, in a small ratios but it was still proven by Portfolio 8 and 10 (24.0 and 14.7\%, respectively). Overall, firms listed on the Main Board of Bursa Malaysia from various industries manage earnings widely after Asian financial crisis. The practice of earnings management depends on the level of operating performances of the firms.

\section{CONCLUSION}

Empirical evidence supports the conception that some firms on the Bursa Malaysia are involved in earnings management to an extent that published financial information are not reliable for decision making. More specifically, negative $\mathrm{CFO}$ firms take income-increasing strategies whereas some firms with extreme performances in both directions tend to employ income-decreasing strategies. For future research, the current study should be expanded to look at the behaviour of accruals in the financial statements to prove the practice of earnings management. The facts that earnings management is widely used using the components of accruals in accounting practice.

\section{IMPLICATIONS}

In the context of Malaysia, MIA Public Relations Committee Chairman, Mohamed (2003) welcomes the government's plan to adopt the accruals-based system in accounting for its revenue and expenditure. This would enable the government to better account for its assets and liabilities and eliminate the timing differences that exist in the current cash-based system, budgeting process will greatly enhanced, reduce the occurrences of cheque fraud and benefit to public as the new system would promote better efficiency, transparency and accountability in the public sector accounts.

In Malaysia, there is lack of study in the earnings management associated with Cash from Operations (CFO). As a developing country, there are thousands of companies listed under various industry sectors for which many local and foreign investors and or stakeholders are dealing with the published financial information for decision-making. Thus, the current study would add to the existing literatures as they would be interested to ascertain the extent of the reliability and relevance of reported earnings in the financial statements can be maintained.

However, the great doubt might be rise when the trend of $\mathrm{CFO}$ and reported net income as profitability measures are extremely showed different trend. In this case, they would realise the facts that earnings management is probably used in the reported earnings. In term of time period, the current study may differ from other previous researches due to different economic environment in Asian financial crisis as the period covered include the year 1999 where one year after Asian region was badly hit by economic turmoil. The academic tradition of looking at far off historical period (i.e., concentrating of the Asian Financial Crisis or the 1980's) maybe suitable merely for academic discussion but it is not useful at all to the general public for financial planning purposes. Moreover, future research can be carried out to investigate contextual factors such as magnitude of accruals, cash from operations as well as net income that are potentially important mitigating the relationship between cash from operations and accruals. The earnings and cash flows variables used can only give partial explanations towards earnings management, primarily because there are also other financial and macroeconomics factors that could possibly explain earnings management.

Thus, it would be interesting to extend the analysis by evaluating other factors either internal or external factors such as company size, economic stability, etc. Possible future research could include a market study associating accruals with stock price reactions for the different portfolios. Another project could investigate 
such areas as IPO firms' earnings management practices and specific methods of earnings management associated with certain type of firm-specific characteristics.

\section{REFERENCES}

Awang, M., M. Mohamed Zain and M.K. Ibrahim, 2004. Disclosure of financial ratio in annual report: Evidence from Malaysian market. University of Technology, MARA.

Bauwhede, H.V., M. Willekens and A. Gaeremynck, 2003. Audit firm size, public ownership and firm's discretionary accruals management. Int. J. Account., 38: 1-22.

Burgstahler, D. and I. Dichev, 1997. Earnings management to avoid earnings decreases and losses. J. Account. Econ., 24: 99-126.

Cahan, S.F., 1992. The effect of antitrust investigations on discretionary accruals: A refined test of the politicalcost hypothesis. Account. Rev., 67: 77-95.

Chaney, P.K. and C.M. Lewis, 1998. Income smoothing and underperformance in initial public offerings. J. Corporate Finance, 4: 1-29.

Chung, R., M. Firth and J. Kim, 2004. Earnings management, surplus free cash flow and external monitoring. J. Bus. Res., forthcom.

Copeland, R.M., 1968. Income smoothing. J. Account. Res., Suppl., 6: 101-116.

DeAngelo, L.E., 1986. Accounting numbers as market valuation substitutes: A study of management buyouts of public stockholders. Account. Rev., 61: 400-420.

DeAngelo, L.E., 1988. Managerial competition, information costs and corporate governance: The use of accounting performance measures in proxy contest. J. Account. Econ., 10: 3-36.

Han, J.C.Y. and S.W. Wang, 1998. Political cost and earnings management of oil companies during the 1990 Persian gulf crisis. Account. Rev., 73: 103-117.
Healy and P.M. Healy, 1985. The effect of bonus scheme on accounting decisions. J. Account. Econ., 7: 85-107.

Holland, D. and A. Ramsay, 2003. Do Australian companies manage earnings to meet simple earnings benchmarks?. Account. Finance, 43: 41-62.

Jones, J.J., 1991. Earnings management during import relief investigation. J. Account. Res., 29: 193-228.

Kanagaretnam, K., G.J. Lobo and D.H. Yang, 2003. Determinants of signaling by banks through loan loss provisions. J. Account. Res., 33: 353-367.

Levitt, A., 1998. The number game, speech delivered at New York University Centre for Law and Business. New York, NY, 28.

Liberty, S.E. and J.L. Zimmerman, 1986. Labour union contract negotiations and accounting choices. Account. Rev., 61: 692-712.

McNichols, M. and G.P. Wilson, 1988. Evidence of earnings management from the provision for bad debts. J. Account. Res., 26: 1-40.

Mohamed, N.J., 2003. Accruals-based accounting system plan gets backing. (2003, October). New Straits Times.

Moses, O.D., 1987. Income smoothing and incentives: Empirical tests using accounting changes. Account. Rev., 62: 358-377.

Perry, S.E. and T.H. Williams, 1994. Earnings management preceding management buyout offers. J. Accoun. Econ., 18: 157-179.

Reitenga, A., S. Buchheit, Q.J. Yin and T. Baker, 2002. CEO bonus pay, tax policy and earnings management. J. Am. Taxation Assoc., 24: 1-23.

Vafeas, N., A. Vlittis, P. Katranis and K. Ockree, 2003. Earnings management around share repurchase: $\mathrm{A}$ note. ABACUS, 39: 262-272.

Yoon, S.S. and G. Miller, 2002. Earnings management of seasoned equity offering firms in Korea. Int. J. Account., 37: 57-78. 